діяльності.

Гуманізація процесу навчання якісно оновлює зміст освіти, тепер він є засобом розвитку внутрішнього світу майбутнього вчителя початкової ланки. Зміна освітніх ідеалів пов'язана з формуванням особистісних якостей особистості, наповненням його уявлень почуттями, ціннісними переживаннями і змістами. Гуманізація навчання акцентує увагу на необхідності розвитку у студентів самостійності, творчої ініціативи, потреби в самовдосконаленні, виявленні моральної позиції, естетичних поглядів тощо. Таке навчання робить студента творцем власної діяльності, що передбачає реалізацію його особистісних функцій у навчальному процесі, відповідальність за хід навчання. Подальшу роботу вбачаємо в розробленні індивідуальних проектів.

\title{
Література
}

1. Залуцький О. Гуманістичні засади в сучасному освітньо-виховному процесі / О. Залуцький // Рідна школа. - 2008. - № 1-2. - С. 69-70. 2. Зязюн І. А. Гуманістична стратегія теорії і практики навчального процесу / І. А.Зязюн // Рідна школа. - 2000. № 3. - С. 8-12. 3. Философский энциклопедический словарь / [гл. ред.: Л. Ф. Ильичёв, П. Н Федосеев, С. М. Ковалёв и др.]. - М. : Сов. энциклопедия, 1983. - 840 с.

УДК 37.013 .41

Кирило Пантелєєв

\section{ОСОБИСТІСНО ЗОРІЄНТОВАНЕ НАВЧАННЯ ЯК РЕСУРС ЗДОРОВ'ЯЗБЕРЕЖЕННЯ МАЙБУТНІХ ОФІЦЕРІВ-ПРИКОРДОННИКІВ}

Пантелєєв К. В. Особистісно зорієнтоване навчання як ресурс здоров'язбереження майбутніх офіцерів-прикордонників.

У статті розглядаються питання розвитку потреби і здатності особистості до саморозвитку у процесі навчання в контексті ідеї здоров'язбереження.

Ключові слова: особистість, розвиток, навчання, потреби і здатності, здоров'язбереження.

Пантелев К. В. Личностно-ориентированое обучение как ресурс здоровьесбережения будущих офицеров-пограничников.

В статье рассматриваются вопросы развития потребности и способности личности к саморазвитию в процессе обучения в контексте идеи здоровьесбережения.

Ключевые слова: личность, развитие, обучение, потребности и способности, здоровьесбережение.

Panteleev K. V. Personality-centered education as a resource of health protection of future border guard officers.

The article studies the issues with regard to developing person's needs and abilities for self-development in a training process in context of health protection.

Key words: personality, development, education, needs and abilities, health protection.

Однією 3 найважливіших проблем на тлі сучасних тенденцій розвитку суспільства $є$ збереження й зміцнення здоров'я особистості. У цьому контексті особливого значення набуває проблема організації здорового способу життя, формування культури здоров'я молодого покоління, адже здоров'я населення є одним із критеріїв розвитку будь-якої країни.

На важливості збереження й зміцнення здоров'я наголошено й у низці нормативних документів, зокрема в Законах України «Про освіту», «Про вищу 
освіту», «Про фізичну культуру і спорт», Цільовій комплексній програмі «Фізичне виховання - здоров'я нації», де здоров'я розглядається як інтегративний показник соціального розвитку суспільства, могутній чинник впливу на економічний i культурний потенціал держави. 3 огляду на це перед системою вищої професійної освіти України висуваються підвищені вимоги з боку суспільства, держави й самого життя щодо пошуку нових підходів до організації процесу професійної підготовки, які б забезпечували створення оптимальних умов задля духовного зростання особистості, реалізації ії психофізичних можливостей, збереження та зміцнення здоров'я.

За даними Міністерства охорони здоров'я України, майже 90 \% учнів, студентів, курсантів військових навчальних закладів мають відхилення у здоров”ї й лише близько $10 \%$ опитуваних уважають себе здоровими. Проте, багато молодих людей свідомо нехтує дотриманням правил особистої гігієни, заняттям фізичною культурою і спортом. Виникає парадоксальна і водночас небезпечна ситуація, коли люди через власні лінощі й недбалість добровільно завдають собі шкоди, скорочуючи тим самим тривалість свого життя. 3 іншого боку, система охорони здоров'я через свою недосконалість не може суттєво впливати на збереження здоров'я людини. Тому особливої значущості набуває проблема підготовки молодої людини до реалізації здорового способу життя в різних умовах іiі життєдіяльності. У цьому аспекті військове середовище, з огляду на специфічність, становить особливий інтерес для дослідників. Зокрема це стосується вищих військових навчальних закладів (ВВН3), у яких навчаються не просто юнаки, а майбутні захисники держави. Військова служба вимагає від них сталого фізичного і психічного здоров’я. Крім того, курсанти ВВНЗ у майбутньому стануть офіцерами й будуть виконувати керівні функції, а отже, отримають можливість впливати на ставлення до здоров’я своїх підлеглих.

Аналіз наукових джерел, присвячених формуванню у військовослужбовців здорового способу життя, дозволив установити, що ця проблема $\epsilon$ недостатньо дослідженою. Серед кола питань, які потребують розв'язання, $\epsilon$ проблема обгрунтування змісту й технологій формування здорового способу життя курсантів у процесі їхньої навчальної й подальшої службової діяльності; розвиток мотивації до збереження й зміцнення власного здоров'я, цілеспрямоване формуванню в курсантів спеціальної професійної працездатності, пов'язаної 3 достатнім розвитком психофізіологічних якостей тощо. Вирішення означених проблем вимагає оптимального розвитку системи бойової та гуманітарної підготовки особового складу, створення адекватних соціально-педагогічних умов, зокрема - упровадження ідей i технологій гуманістичної педагогіки, переходу від авторитарної моделі військовонавчального процесу до особистісно зорієнтованої. Це потребує переосмислення теоретико-методологічних i методичних основ навчання військовослужбовців. Особистісно зорієнтована модель навчання повинна грунтуватися на визнанні особистості військовослужбовця як суб'єкта взаємодії, орієнтації на розкриття потенційних можливостей воїнів і забезпечити їх максимальну реалізацію в умовах військово-професійної освіти й військової служби.

У контексті збереження й зміцнення здоров'я тих, хто навчається, особистісно зорієнтований підхід, утілений у відповідних технологіях, дозволяє створювати максимально повні можливості для життєвого i професійного самовизначення курсантів, оскільки розвиток фізичного, психічного й духовного здоров'я, усвідомлений вибір здорового способу є також i чинником, і умовою життєвого успіху, благополуччя, самореалізації й повноцінного функціонування.

Концепція особистісно зорієнтованої освіти розглядається нами як основа i проект цілісної здоров'язберігальної педагогічної системи, реалізація якої створює всі 
необхідні умови для розвитку особистісних функцій майбутнього офіцераприкордонника, включаючи вибір цілей і способів самореалізації, усвідомлення свого «Я», вияв відповідальності і творчості в подальшій професійній діяльності. У контексті збереження і зміцнення психологічного й соціального здоров'я курсантів метою особистісно зорієнтованої освіти слід уважати створення умов задля повноцінного розвитку таких якостей індивіда: вибірковості (здатність до вибору); рефлексії (уміння переосмислювати своє буття); відповідальності (відповідно до формулювання «Я відповідаю за все»); автономності особистості (звільнення від впливу багатьох чинників), тобто закласти в людині механізми самореалізації, саморозвитку, адаптації, саморегуляції, самозахисту, самовиховання тощо для становлення самобутнього особистісного образу й діалогічної взаємодії $з$ людьми, природою, культурою, цивілізацією [1], що загалом і дозволить бути здоровим у всіх вимірах.

Технології особистісно зорієнтованого навчання припускають розвиток особистісних (соціально значимих) якостей курсантів за допомогою навчальних предметів. Спектр соціально значимих якостей досить різноманітний: розумові, мовні, поведінкові, комунікативні, творчі, фізичні, емоційно-почуттєві. Особистісно зорієнтований підхід створює оптимальні умови для самовираження курсантів, оскільки самовираження в цьому випадку стає ефективним способом закріплення тих або інших особистісних якостей i забезпечення психологічного й соціального здоров'я.

Технологія диферениійованого, у тому числі індивідуалізованого навчання опирається на вивчення особливостей людини (соціально-демографічних, соціальнопсихологічних, індивідуально-особистісних, екзістенціально-особистісних). Ї̈і мета виявити психологічну й методичну допомогу майбутнім фахівцям, щоб їх навчальна діяльність була успішною. Отже, ця технологія дозволяє, насамперед, ураховувати особливості аудиторії, а також створювати умови для самовираження тих, хто навчається підбирати прийоми, що впливають на збереження інтересу до навчального матеріалу. Знижується тривожність тих, хто навчається, формується їхня адекватна самооцінка.

Особистісно зорієнтований підхід передбачає співпрацю та співтворчість слухача і викладача. Отже, головною дійовою особою навчального процесу за таких умов стає слухач. Завдання викладача - простежити динаміку його розвитку, визначити особисті переваги у роботі з навчальним матеріалом, тобто пізнати того хто навчається як особистість, розкрити та розвинути його індивідуальні здібності [2; 4; 7].

Для реалізації цього завдання на практиці викладачеві необхідно:

- сприяти зацікавленості кожного слухача в роботі групи за допомогою чіткої, зрозумілої та доступно сформульованої мотиваційної установки;

- використовувати різноманітні форми та методи організації навчальної діяльності, орієнтовані на конкретного слухача;

- стимулювати слухачів до висловлювання, використання різних способів розв'язання ситуативних завдань без страху помилитися.

- створювати на занятті такі педагогічні ситуації, які надають змогу кожному слухачеві проявити ініціативу, самостійність, підтримувати прагнення кожного знаходити власний спосіб роботи, аналізувати й оцінювати роботу інших;

- використовувати різноманітні види пізнавальної діяльності задля розвитку мотиваційного, змістово-операційного та вольового складників пізнавальної самостійності тих, хто навчається. 
При цьому слухачі отримують більше самостійності, краще осмислюють мету та результати своєї праці, усвідомлюючи, що вони є не об'єктом, а суб'єктом навчальної діяльності; викладач же стає доброзичливим помічником, що зацікавлений у долі кожного слухача. Таким чином, відбувається переорієнтація слухачів від навчання («нехай мене навчать») до учіння («прагну все знати») [5; 6].

На наш погляд, моніторинг результатів роботи 3 використанням особистісно зорієнтовного підходу в навчанні полягає не тільки в кількості та якості оцінок, отриманих слухачами, а передовсім, у характеристиці їхніх інтелектуальних умінь, навичок, творчих здібностей.

Отже, особистісно зорієнтоване навчання можна розглядати як утілення загальнодидактичного принципу індивідуального підходу у процесі навчання. Важливим підгрунтям для реалізації особистісно-орієнтованого підходу в практиці індивідуалізації професійної підготовки слухачів академії можна вважати теорію Л. Виготського про зону найближчого розвитку [3].

Перша зона - це зона актуального розвитку. До цієї зони включено завдання, які людина може виконати сама без допомоги викладача. Наприклад, на першому курсі навчання, ще до вивчення тематики «Рукопашний бій», слухачі на запитання «3 яких частин складається удар рукою прямо?» відповідають, що до таких частин належать нанесення удару, повернення в попереднє положення бойової стійки. Викладач узагальнює й розширює відповіді слухачів 3 подальшим показом на схемі й демонструванням його наживо з поясненням.

Зона найближчого розвитку - це зона «наступного дня», в межах розвитку якої зосереджено завдання, які слухач самостійно виконати не може, але може 3 ними впоратися з допомогою викладача. Те, що сьогодні є зоною найближчого розвитку, завтра у процесі навчання повинно стати зоною актуального розвитку. Викладач не повинен давати готову інформацію, адже таке навчання може загальмувати мислення того хто навчається. А за допомогою грамотно дібраних запитань педагог підводить слухачів до правильної відповіді, розв'язку. Наприклад, на початку занять 3 вивчення теми «Рукопашний бій» на запитання «Чи можна виконати один прийом різними способами ?» слухачі надати відповідь не можуть, а наприкінці виучуваної теми легко його виконують.

Отже, щоб забезпечити індивідуальний підхід на практиці треба ставити перед кожним слухачем своє завдання, яке відповідає на даний час стану його зони розвитку. Якщо для всієї групи поставити одне завдання, то для одних слухачів воно знаходитиметься в зоні актуального розвитку, (що не сприятиме їх просуванню вперед), а для інших - у зону найближчого розвитку. Однак повноцінній реалізації положень особистісно зорієнтованого підходу на практиці, на нашу думку, заважає групова система навчання на заняттях з фізичної підготовки. По-перше, щоб підійти індивідуально до кожного слухача, необхідно знати його психологічні, фізіологічні та соціальні особливості тощо. Так, психологи вказують на кілька десятків вияву індивідуальних особливостей особистості. Це стосується, зокрема, домінування різних видів пам'яті (короткочасна, довготривала, оперативна, рухова, зорова, слухова, емоційна, словесно-логічна), уваги, сприйняття, уяви, мислення, темпераменту, характеру тощо. По-друге виявити всі психологічні, фізіологічні й соціальні особливості викладач не може без допомоги психолога, лікаря, соціолога, інших фахівців. По-третє, навіть якщо теоретично припустити, що в кожного слухача виявлено його індивідуальні особливості, то викладачеві складно опанувати таким великим масивом інформації. 
Отже, для того щоб навчальний процес розвивався максимально продуктивно, потрібно оптимізувати навчальне навантаження викладача в напрямі зменшення обсягу групового навчання на користь індивідуально-диференційовано через утворення малих груп слухачів 3 близькими індивідуально-особистісними характеристиками.

У контексті реалізації особистісно зорієнтованого підходу особливого значення набуває ненасильницьке навчання, що дозволяє використовувати психологічні й педагогічні засоби конструктивної взаємодії педагогів і тих, хто навчається, допомагає відійти від авторитарного й маніпулятивного стилю керування на занятті, дозволяє ефективно використовувати різноманітні форми колективної розумової діяльності, що створює сприятливий психологічний мікроклімат, попереджає гіподинамію через різноманітні форми колективної діяльності, сприяє емоційному благополуччю слухачів.

Використовуючи технологію рефлексивного навчання, викладач має можливість відслідковувати у процесі заняття рівень розуміння слухачами навчального матеріалу, особливості їх психологічного стану (ступінь утоми, стомлюваності, зацікавленості), ставлення до навчального матеріалу й заняття в цілому за допомогою налаштування оперативного зворотного зв'язку. Рефлексивне навчання допомагає створити умови для самовираження особистості, ініціює різноманітні види діяльності.

Ефективне застосування технологій особистісно зорієнтованого навчання сприяє створенню здоров'язберігального освітнього середовища.

\section{Література}

1. Балл Г. В. Гуманістичні засади педагогічної діяльності: підручник / Г. В. Балл. - К. : Академія. - 1994. - 311 с. 2. Бондаревская Е. В. Гуманистическая парадигма личностно ориентированного образования / Е. В. Бондаревская // Педагогика. - 1997. - № 4. - С. 12-17. 3. Выготский Л. С. Мышление и речь / Л. С. Выготский. - М. : Лабиринт, 2005. - 352 с. 4. Зеер Э. Ф. Личностно ориентированное профессиональное образование/ Э. Ф. Зеер, Г. М. Романцев // Педагогика. - 2002. - № 3. - С. 16-21. 5. Подмазин С. И. Проблемы содержания личностно ориентированного образования / С. И. Подмазин // Завуч. -2001 . - № 11. С. 2-3. б. Севрук А. И. Здоровьезберегающий урок / А. И. Севрук, Е. А. Юнина // Школьные технологи. - 2004. - № 3. - С. 201-202. 7. Якиманська І. С. Технологія особистісно-орієнтованого навчання в сучасній школі / I. С. Якиманська. - М. : Вересень, 2000. - 188 с.

УДК 37.011.3-051

Наталя Поліщук

\section{ВИМОГИ ДО ОСВІТИ ТА ПІДГОТОВКИ ДУХОВНОГО ВЧИТЕЛЯ В ЕПОХУ ІНФОРМАЦЙНО-ВИСОКОТЕХНОЛОГІЧНОГО НАУКОВО-ТЕХНІЧНОГО ПРОГРЕСУ}

Поліщук Н. В. Вимоги до освіти та підготовки духовного вчителя в епоху інформаційно-високотехнологічного науково-технічного прогресу.

У статті розглядаються проблеми трансформації освітньої системи в умовах інформаційно-високотехнологічного суспільства, в якому інформація, знання, технологія розуміються як основні соціальні цінності. Показано, що необхідна модернізація сучасної освіти в контексті підвищення ефективності іiі впливу на професійне самовизначення особистості в системі ринкових та демократичних трансформацій, а також у контексті зростання духовності молоді. 